\title{
Immunofluorescence localization of ovine placental lactogen
}

\author{
S. Reddy and W. B. Watkins \\ Postgraduate School of Obstetrics \& Gynaecology, University of Auckland, \\ Auckland, New Zealand
}

Summary. Immunoreaction to ovine placental lactogen was found in binucleate and uninucleate cells of the fetal trophoblast.

\section{Introduction}

Placental proteins with lactogenic activity have been demonstrated, by means of bioassay and radioreceptor assay techniques, in rodents, ruminants and primates (Forsyth, 1974; Kelly, Robertson \& Friesen, 1974; Talamantes, 1975; Kelly, Tsushima, Shiu \& Friesen, 1976).

We have recently purified sheep placental lactogen (Reddy \& Watkins, 1977) by using a modification of the method described by Chan, Robertson \& Friesen (1976). This preparation of placental lactogen possessed a lactogenic activity equivalent to $1 \mathrm{mg}$ ovine prolactin/mg protein and a growth hormone-like activity equivalent to $0.8 \mathrm{mg}$ human growth hormone/mg protein, as determined by radioreceptor assays with rabbit mammary gland and rabbit liver, respectively. The purity of this preparation was further confirmed by the absence of cross-reactivity when tested against rabbit antisheep serum by microimmunoelectrophoresis and microimmunodiffusion. In the present study the immunofluorescence localization of this hormone is described.

\section{Methods}

Purified ovine placental lactogen $(250 \mu \mathrm{g}$ : see Reddy \& Watkins, 1977$)$ in an emulsion of $500 \mu 1$ Freund's complete adjuvant (Difco) and $500 \mu 10 \cdot 1 \mathrm{M}$-ammonium bicarbonate (pH 8.3) was injected subcutaneously in multiple sites along the back of New Zealand White male rabbits. The first administration of antigen was accompanied by an intramuscular injection of Bordetella pertussis vaccine $\left(2 \times 10^{10}\right.$ organisms) to enhance the immune response of the animal, and 4 subsequent injections were given at 2 -week intervals. Blood was collected 6 weeks after the first injection and the serum collected was stored at $-20^{\circ} \mathrm{C}$ until use. Before immunofluorescence histology, the antiserum was absorbed with acetone-dried sheep liver powder (Nairn, 1969) and then passed through a Millipore filter $(0 \cdot 1 \mu \mathrm{m}$ pore size). Pregnant ewes (6) between 100 and 130 days of gestation were killed by severing the jugular vein. The placental cotyledons were removed, washed free of blood, cut into quarters and fixed in Bouin's fluid for 2 weeks. After dehydration through an alcohol series, the tissue blocks (approximately $1 \mathrm{~cm}$ cubes) were cleared in xylol and embedded in Paraplast (Sherwood Med. Ind., Missouri, U.S.A.).

Immunofluorescence was carried out on $4 \mu \mathrm{m}$ thick tissue sections with (a) antiserum to ovine placental lactogen, diluted 10-fold in phosphate-buffered saline (PBS), pH 7.6, and (b) sheep antirabbit $\gamma$-globulin conjugated to fluorescein isothiocyanate (Wellcome Laboratories, U.K.), diluted 10 -fold in PBS. Each reagent was allowed to react for $30 \mathrm{~min}$ at $37^{\circ} \mathrm{C}$. The tissue section was then washed with PBS for $15 \mathrm{~min}$. The sections were mounted in glycerol-saline and the immunofluorescence was observed with a Leitz Ortholux fluorescence microscope. The specificity of the immunoreaction was confirmed by replacing the antiserum with preimmune serum, PBS, rabbit antiserum to bovine growth hormone, or rabbit anti-sheep serum prepared by absorbing the antiserum to ovine placental lactogen $(100 \mu \mathrm{l})$ with a preparation of sheep placental lactogen $(250 \mu \mathrm{g})$. The immunofluorescence test was similarly applied to sheep liver, kidney and pituitary tissues. Tissue sections were also stained for PAS-positive structures. Downloaded from Bioscientifica.com at 04/26/2023 01:04:21PM 


\section{Results}

Positive staining was seen only in sections which had been treated with antiserum to ovine placental lactogen. The immunofluorescence was localized in large binucleate cells in the epithelium of the fetal chorionic villi and in the uninucleate cells which comprise the fetal trophoblast (Plate 1). These results were consistent for tissues from all 6 animals investigated.

\section{Discussion}

The localization of ovine placental lactogen found in the present study confirms that briefly reported by Dubois, Martal \& Djiane (1976), but the relationship between the two types of the lactogen-containing cells is unknown. Boshier (1969) demonstrated that the large binucleate cells in the chorionic villi of the sheep are PAS-positive (confirmed in the present study) and appear within 1 week of embryonic attachment. Protein with the ability to bind to mammary gland membranes has also been demonstrated in the trophoblast of sheep placentae of 16-17 days gestation (Martal \& Djiane, 1977), but it has yet to be shown whether the binucleate cells are responsible for synthesis of the placental lactogen at this early stage of fetal development.

This work was financed by the Medical Research Council of New Zealand.

\section{References}

BoshieR, D.P. (1969) A histological and histochemical examination of implantation and early placentome formation in sheep. J. Endocr. 19, 51-61.

Chan, J.S.D., Robertson, H.A. \& Friesen, H.G. (1976) The purification of and characterization of ovine placental lactogen. Endocrinology 98, 65-76.

Dubois, M., Martel, J. \& Ditane J. (1976) Immunofluorescence localization of placental lactogen. Proc. Sth Int. Congr. Endocr. Hamburg, p. 25.

ForsyTh, I.A. (1974) A comparative study of placental lactogenic hormones: a review. In Lactogenic Hormones, Fetal Nutrition and Lactation, pp. 49-67. Eds J. B. Josimovich, M. Reynolds \& E. Cobo. John Wiley, New York.

Kelly, P.A., Robertson, H.A. \& Friesen, H.G. (1974) Temporal pattern of placental lactogen and pro- gesterone secretion in sheep. Nature, Lond. 248, 435-437.

Kelly, P.A., Tsushima, T., Shiu, R.P.C. \& Friesen H.G. (1976) Lactogenic and growth hormone-like activities in pregnancy determined by radioreceptor assays. Endocrinology 99, 765-774.

MarTal, J. \& DJiane, J. (1977) The production of chorionic somatomammotrophin in sheep. $J$. Reprod. Fert. 49, 285-289.

NAIRN, R.C. (1969) Fluorescent Protein Tracing. Livingstone, Edinburgh.

Reddy, S. \& Watkins, W.B. (1977) Purification and characterization of ovine placental lactogen. N.Z. med.J. (in press).

Talamantes, F. (1975) Comparative study of the occurrence of placental prolactin among mammals. Gen. comp. Endocr. 27, 115-121.

Recejved 22 July 1977

\section{EXPLANATION OF PLATE}

Large binucleate cells (single arrow) in the epithelium of the chorionic villi and in the uninucleate cells present in the fetal trophoblast (double arrow), stained specifically for ovine placental lactogen 2 by $\mathbf{~ i m}-04: 21 \mathrm{PM}$ munofluorescence $(a, b)$ and for PAS-positive material (c). (a, c) $\times 238$; (b) $\times 590$. 


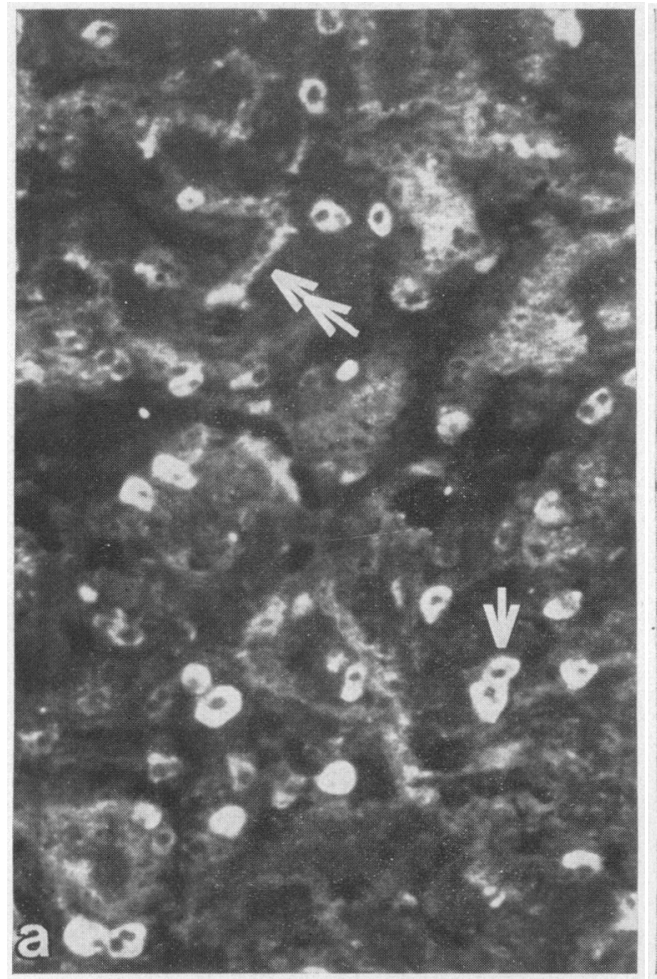

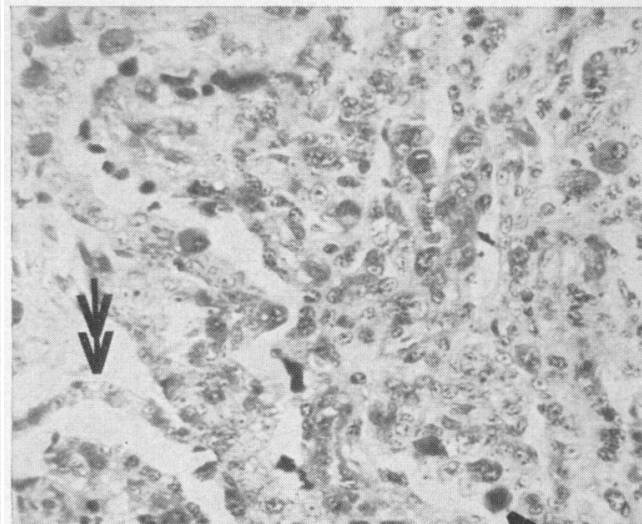

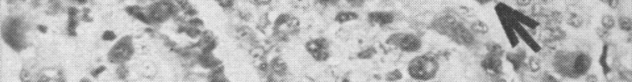

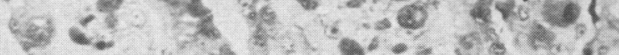
$80^{3}-6$ -

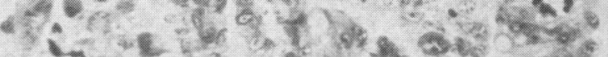

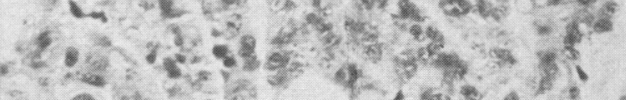

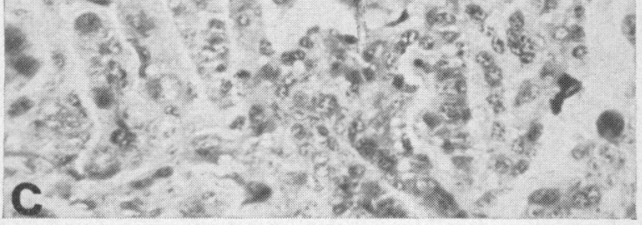

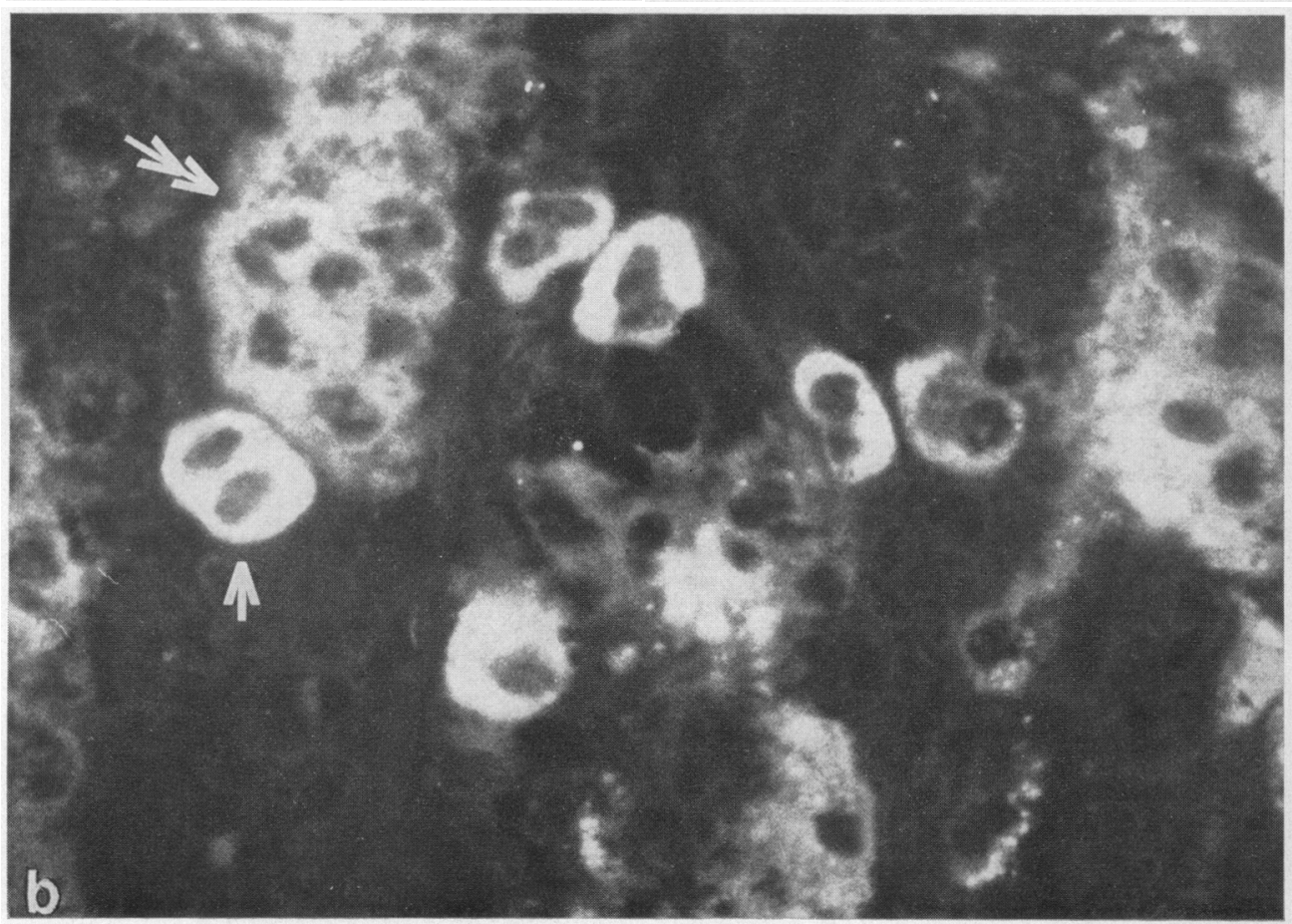

